\title{
Osteoporozda Depresyon ve Yaşam Kalitesine Etkisi
}

\author{
Depression in Osteoporosis and Effects on Quality of Life \\ Şule Şahin Onat, Sibel Ünsal Delialioğlu, Seda Biçer, Sumru Özel \\ Ankara Fizik Tedavi Eğitim ve Araştırma Hastanesi, Ankara, Türkiye
}

\section{Özet}

Amaç: Bu çalışmanın amacı osteoporozlu hastalarda depresyon gelişimi için risk faktörlerini belirlemek ve depresyonun osteoporozlu hastalarda yaşam kalitesine etkisini ölçmektir.

Gereç ve Yöntem: Çalışmaya polikliniğimize başvuran 125 osteoporoz tanısı konulmuş hasta alındı. Hastalara yaş, cinsiyet, medeni durum, eğitim düzeyi, meslek, boy, kilo, alkol kullanımı, sigara kullanımı, fiziksel aktivite düzeyi, süt tüketimi, geçirilmiş frajilite kırı̆ı öyküsünü içeren sorgulama formu dolduruldu. Kemik mineral yoğunluğu ölçümü DEXA ile lomber bölge ve femur boynundan yapıldı. Olguların torakal ve lomber vertebra grafileri çekilerek kompresyon kırıkları olup olmadığı kaydedildi. Sırt ağrısını değerlendirmek için Görsel Analog Skala (GAS) kullanıldı. Hastaların depresyonunu değerlendirmek için Beck Depresyon Ölçeği (BDÖ), yaşam kalitesini değerlendirmek için Avrupa Osteoporoz Kurumu Yaşam Kalitesi Anketi (QUALEFFO) kullanıldı.

Bulgular: Çalışmaya alınan 125 hastanın 57'sinde $(\% 45,6)$ depresyon varken 68'inde $(\% 54,4)$ depresyon bulunmamaktaydı. Depresyonu olan osteoporoz hastalarında yaş ortalaması, okur-yazar olmama durumu, azalmış fiziksel aktivite düzeyi depresyonu olmayanlardan yüksekti. Osteoporoz risk faktörlerinden vertebral kompresyon kırı̆̆ı, ailede kırık hikayesi, düşmeye yatkınlık ve osteopeninin depresyonu olan grupta depresyonu olmayanlardan istatistiksel olarak anlamlı olarak fazla olduğu bulundu. Hem lomber hem de femur T ve Z değerleri, GAS değerleri depresyonu olan osteoporoz hastalarında depresyonu olmayanlardan istatistiksel olarak daha yüksekti $(p<0,05)$. QUALEFFO yaşam kalitesi ölçeğinin tüm alt parametreleri ve toplam değeri depresyonu olan osteoporoz hastalarında depresyonu olmayanlardan istatistiksel olarak anlamlı şekilde daha yüksekti $(p<0,05)$. BDÖ skoruyla QUALEFFO yaşam kalitesi ölçeğinin alt parametre skorları arasında pozitif anlamlı korelasyon bulundu $(p<0,05)$.

Sonuç: Depresyonun artmış kemik kaybı olan bireylerde yaşam kalitesinin daha da düşmesine neden olduğu ortaya konuldu. (Türk Osteoporoz Dergisi 2013;19: 58-64)

Anahtar kelimeler: Osteoporoz, depresyon, yaşam kalitesi

\section{Summary}

Objective: The aim of this study was to identify risk factors for the development of depression in patients with osteoporosis, and to measure the psychosocial effects to the change in quality of life.

Material and Methods: 125 patients with osteoporosis were included in the study. A questionnaire was completed which was including age, sex, marital status, education level, occupation, height, weight, alcohol use, smoking, physical activity level, milk consumption, previous fragility fracture of the patients. Bone mineral density of the lumbar spine and femoral neck were measured with DEXA. Back and lumbar compression fractures of the individuals were recorded by back and lumbar radiography. To evaluate back pain, Visual Analog Scale (VAS) was used. To assess depression in patients, Beck Depression Inventory (BDI) was used, and to assess the quality of life the European Council of Osteoporosis Quality of Life Questionnaire (QUALEFFO) was used.

Results: 125 patients were included in the study, 57 patients (45.6\%) had depression and 68 patients (54.4\%) had not depression. The average age, illiteracy status, reduced physical activity level were higher in the patients with depression than the patients without depression. Vertebral compression fracture, family history of fracture, fall predisposition, and osteopenia in the risk factors of osteoporosis were found statistically significantly higher in the group with depression than the group without depression. Both lumbar and femoral T and Z values, and VAS values were significantly higher in the patients with depression than the patients without depression $(p<0.05)$. The total value and all sub-parameters of quality of life scale QUALEFFO were significantly higher in patients with depression than patients without depression $(p<0.05)$. Positive significant correlation was found between BDI scores and sub-parameters of QUALEFFO scores $(p<0.05)$.

Conclusion: Depression in individuals with increased bone loss was shown to lead to a further decrease in the quality of life. (Turkish Journal of Osteoporosis 2013;19: 58-64)

Key words: Osteoporosis, depression, quality of life 


\section{Giriş}

Ilerleyen yaşla birlikte kemik kaybının ve depressif semptomların arttığı bilinmektedir. Zaman geçtikçe bu iki durumun birbiriyle ilişkisi gündeme gelmiştir. Peki depresyon mu artmış kemik kaybı için risk faktörüdür yoksa artmış kemik kaybı mı osteoporoz için risk faktörüdür? sorusu tam açıklığa kavuşturulamasa da net ilişkileri birçok kez ortaya konulmuştur (1-3). Bu çift yönlü ilişkinin bir başka boyutu ise hem depresyon hem de osteoporoz bireyin yaşam kalitesini kötüleştirmektedir (2-4). Şimdiye kadar ki bu konuda yapılmış çalışmalarda araştırma örneklemini ya premenapozal ya da postmenapozal kadınlar oluşturmaktaydı (2-4). Çalışmamızın daha önceki çalışmalardan farkı her iki cinsiyette de hem depresyon ve osteoporozla ilişkili faktörleri hem de depresyonun yaşam kalitesine etkisini göstermesi olmuştur. Çünkü bu çalışmanın amacı osteoporozlu hastalarda depresyon gelişimi için risk faktörlerini belirlemek ve bu psikososyal değişimin yaşam kalitesine etkisini ölçmekti.

\section{Gereç ve Yöntem}

Kesitsel olan çalışmamıza fizik tedavi polikliniğine başvuran Dünya Sağlık Örgütü (DSÖ) kriterlerine göre dual enerji X-ray absorpbsiyometre (DXA) ile osteoporoz tanısı konulmuş 125 hasta başvurularına göre ardı sıra alındı. Hastane lokal etik kurulundan onay alındı. Hastalar çalışma ile ilgili bilgilendirilerek hasta onamları alındı.

Hastalara yaş, cinsiyet, medeni durum (evli\evli değil), meslek (aktif çalışan\aktif çalışmayan), eğitim durumu (okuryazar\okuryazar değil), alkol kullanımı (içmiyor\sosyal içici\sürekli içici), sigara kullanımı (paket\gün\yı), kahve tüketimi (bardak\gün), fiziksel aktivite düzeyi (düzenli egzersiz yapıyor \ara sıra egzersiz yapıyor\ hiç egzersiz yapmıyor), boy, kilo, vücut kütle indexi, süt ve/veya eşdeğer tüketimi, oral steroid kullanım öyküsü, geçirilmiş frajilite kırığı öyküsü, ek hastalık varlığı ve osteoporoza neden olabilecek ilaç kullanımı ve soygeçmişinde hastada geçirilmiş hastalıklar, fragilite kırığı ve ailede kırık öyküsünü içeren sorgulama formu dolduruldu. Günlük kalsiyum alımını hesaplamak için hastalara günde tüketilen süt (su bardağı/gün), peynir (dilim/gün) ve yoğurt miktarı (kase/gün) sorgulandı ve her bir birim 200 mg kalsiyum olarak hesaplandı (5). Osteoporoz risk faktörleri Kanada tanı ve tedavi rehberine göre belirlenen majör ve minör risk faktörleri olarak kaydedildi (6).

Fiziksel aktivite düzeyinin değerlendirilmesinde, sadece günlük yaşam aktivitelerini içeren aktiviteleri yapan ve 30 dakikadan daha az yürüyüş yapanlar 'düşük fiziksel aktivite düzeyi', 30 dakikadan fazla günlük yürüyüş yapanlar 'ara sıra egzersiz yapıyor' ve düzenli egzersiz uygulayanlar ise 'düzenli egzersiz yapıyor' olarak gruplandırıldı.

Hastaların boy ve kilo ölçümlerinden vücut kütle indeksi (VKI) $\left(\right.$ kilo/(boy) $\left.{ }^{2}\right) \mathrm{kg} / \mathrm{m}^{2}$ cinsinden hesaplandı. Vücut yapısının VKI'nin $\leq 18,5$ zayıf, 18,5-24,9 ideal kilolu, 25-29,9 fazla kilolu, VKi $\geq 30$ obez olarak ayrıldı (7).

Kemik mineral yoğunluğu (KMY) ölçümü lomber vertebralardan (L1-L4 arası anterior pozisyonda) ve proksimal femurdan DXA cihazı (Lunar DPX-IQ) ile değerlendirildi. Olguların iki yönlü torakal ve lomber vertebra grafileri çekilerek tüm vertebralarda ön, orta, arka yükseklikler ölçüldü ve bir vertebranın üç yükseklik ölçümünden (ön, orta, arka) en az biri en yakın normal vertebranın yükseklik ölçümünden \%20 azalmış ise bu vertebral kırık olarak kabul edildi (8). Sırt ağrısını değerlendirmek için Görsel Analog Skala (GAS) kullanıldı.

Hastaların depresyonunu değerlendirmek için Beck Depresyon Ölçeği (BDÖ) kullanıldı. Beck Depresyon ölçeği genel depresif durumla ilgili davranış ve duyguları sorgulayan 21 sorudan oluşur. Yüksek skor, artmış depresif semptom şiddetini gösterir (9). Erişkinlerde depresyon riskini, depresif belirtilerin düzeyini ve şiddet değişimini ölçmek üzere geliştirilmiştir. Türkçe geçerlilik ve güvenilirlik çalışması Hisli tarafından yapılmıştır (10). Toplam 21 kendini değerlendirme cümlesi içermektedir. Her madde 0-3 arasında artan puan alır ve toplam 0-63 arasında değişir. Ölçeğin Türkçe için geçerlilik ve güvenirlik makalesinde kesme puanı 17 olarak kabul edilmiştir. On sekiz ve üzerindeki puanlar orta ve ileri derecede depresyonun göstergesi olarak kabul edilmektedir. Güvenilirlik çalışmasında Croanbach alfa katsayısı 0,80 olarak bulunmuştur.

Yaşam kalitesini değerlendirmek için Avrupa Osteoporoz Kurumu Yaşam Kalitesi Anketi (QUALEFFO) kullanıldı. Avrupa Osteoporoz Kurumu Yaşam Kalitesi Anketi (QUALEFFO-41) osteoporozda yaşam kalitesi değerlendirilmesinde yaygın olarak kullanılan ve pek çok ülkede geçerlilik çalışmaları yapılmıs, tekrarlanabilir, hastalarla kontrol grubu arasındaki farklılıkları açıkça ortaya koyabilen bir ölçektir. Lips ve ark.ları tarafından yapılan bir geçerlilik çalışmasında yeniden test edilme özelliğinin ve iç tutarlığının iyi olduğu saptanmış, vertebra kırığı olan hastalar ve kontroller arasındaki farkı ayırt edebildiği gösterilmiştir (11). QUALEFFO'nun Türkçe versiyonu Koçyiğit ve arkadaşları tarafından hazırlanmış ve testin güvenilirlik ve geçerlilik çalışması yapılmıştır (12). QUALEFFO-41, ağrı (5 madde), fiziksel fonksiyon (17 madde), sosyal etkinlik (7 madde), genel sağlık değerlendirmesi (3 madde) ve zihinsel fonksiyon (9 madde) gibi; sağlığın beş boyutunu inceleyen 5 alt ölçekten oluşur. SF-36 ile karşılaştıııldığında ağrı, fiziksel fonksiyon ve sosyal fonksiyon alanlarında daha iyi performans gösterdiği saptanmıştır (11). QUALEFFO-41 ölçeğindeki soruların yanıtları seçenek sırasıyla 1'den (sağlıklı) 5'e (sağlıksız) kadar puanlanmaktadır. 33, 34, 35, 37, 39 ve 40. sorular puanlanırken, seçeneklerin sırası ters çevrilerek sıralamanın diğer sorularda olduğu gibi en iyi sağlık durumundan (1 puan), en kötü sağlık durumuna (5 puan) doğru olması sağlanmaktadır. Üç seçenekli sorular $(23,24,25,26)$ için birinci soruya 1, ikinci soruya 3 , üçüncü soruya 5 puan verilmektedir. Dört seçenekli sorular (27, $28,29)$ için birinci soruya 1, ikinci soruya 2.3, üçüncü soruya 3.6 ve dördüncü soruya 5 puan verilmiştir. 24, 26 ve 29. sorular için "bu soru benim için geçerli değil" ya da "sinema ya da tiyatroya gitmiyorum" seçenekleri için puan verilmemiştir (13). Bölüm puanı ve toplam puan, puanların 100 üzerinden yapılan bir ölçüme aktarılmasıyla hesaplanmaktadır. Ölçekteki her bir alt grup ve toplam sonuç için, 0 puan en iyi sağlık durumunu gösterirken, 100 puan en kötü sağlık durumunu göstermektedir (13). 


\section{İstatistiksel Analiz}

İstatistiksel analizde SPSS (Statistical Package for Social Sciences) 20.0 istatistik paket programı kullanıldı. p $\leq 0,05$ degerleri anlamlı kabul edildi. Tanımlayıc istatistikler ortalama \pm standart sapma olarak gösterildi. Depresyonu olan ve olmayan osteoporotik hastalar arasında kategorik verilerin karşılaştırılmasında ki-kare testi, gruplar arasında ortalamalar yönünden farkın önemliliğ Student's t testi ile değerlendirildi. BDÖ skoruyla QUALEFFO yaşam kalitesi ölçeğinin alt parametre skorları arasındaki ilişki Pearson korelasyon analizi ile incelendi.

\section{Bulgular}

Çalısmaya alınan toplam 125 bireyin 95'i kadın (\%76), 30'u

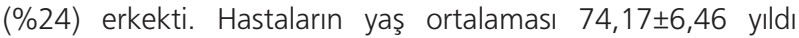

Hastaların 57'sinde $(\% 45,6)$ depresyon varken 68 'inde $(\% 54,4)$ depresyon bulunmamaktaydı. Depresyonu olan osteoporoz hastalarının yaş ortalaması $(76,56 \pm 5,89)$ depresyonu olmayan osteoporoz hastalarının yaş ortalamasından $(72,17 \pm 6,27)$ istatistiksel olarak anlamlı şekilde yüksek bulundu $(p=0,0001)$. Hastaların demografik ve klinik özellikleri ilgili tabloda özetlenmiştir (Tablo 1). Buna göre depresyonu olan osteoporoz hastalarında okuryazar olmama durumunun depresyonu olmayan osteoporoz hastalarından istatistiksel olarak anlamlı şekilde yüksek olduğu görülmektedir $(p<0,05)$. Fiziksel aktivite düzeyi açısından incelendiğinde depresyonu olan osteoporoz hastalarında egzersiz yapma oranlarının istatistiksel olarak anlamlı şekilde düşük olduğu görüldü $(p<0,05)$.

Osteoporoz için majör ve minör risk faktörlerinin depresyonu olan ve olmayan osteoporoz hastalarında dağııımı ilgili

Tablo 1. Depresyonu olan ve olmayan osteoporoz hastalarının özellikleri

Depresyonu olan $n=57(\%)$

\section{Cinsiyet}

\begin{tabular}{|c|c|c|c|}
\hline Kadın & $46(80,7)$ & $49(72,1)$ & 0,260 \\
\hline Erkek & $11(19,3)$ & $19(27,9)$ & \\
\hline \multicolumn{4}{|l|}{ Medeni durum } \\
\hline Evli & $34(59,6)$ & $48(70,6)$ & 0,200 \\
\hline Evli değil & $23(40,4)$ & $20(29,4)$ & \\
\hline \multicolumn{4}{|l|}{ Meslek } \\
\hline Aktif çalışmayan & $56(98,2)$ & $62(91,2)$ & 0,087 \\
\hline Aktif çalışan & $1(1,8)$ & $6(8,8)$ & \\
\hline \multicolumn{4}{|l|}{ Eğitim durumu } \\
\hline Okuryazar & $22(38,6)$ & $41(60,3)$ & $0,016^{*}$ \\
\hline Okuryazar değil & $35(61,4)$ & $27(39,7)$ & \\
\hline \multicolumn{4}{|l|}{ Alkol kullanımı } \\
\hline İçmiyor & $54(94,7)$ & $63(92,6)$ & 0,634 \\
\hline Sosyal içici & $3(5,3)$ & $5(7,4)$ & \\
\hline \multicolumn{4}{|l|}{ Sigara kullanımı } \\
\hline Var & $8(14)$ & $13(19,1)$ & 0,449 \\
\hline Yok & $49(86)$ & $55(80,9)$ & \\
\hline \multicolumn{4}{|l|}{ Fiziksel aktivite düzeyi } \\
\hline Düzenli egzersiz yapan & $2(3,5)$ & $8(11,8)$ & $0,023^{*}$ \\
\hline Arasıra egzersiz yapan & $15(26,3)$ & $28(41,2)$ & \\
\hline Hiç egzersiz yapmayan & $40(60,2)$ & $32(47,1)$ & \\
\hline \multicolumn{4}{|l|}{ VKi } \\
\hline İdeal kilolu & $7(12,3)$ & $13(19,1)$ & 0,453 \\
\hline Fazla kilolu & $22(38,6)$ & $28(41,2)$ & \\
\hline Obez & $28(49,1)$ & $27(39,7)$ & \\
\hline \multicolumn{4}{|l|}{ Diyette yetersiz kalsiyum alımı } \\
\hline Var & $43(75,4)$ & $41(60,3)$ & 0,072 \\
\hline Yok & $14(24,6)$ & $27(39,7)$ & \\
\hline
\end{tabular}


Tablo 2. Depresyonu olan ve olmayan osteoporoz hastalarında risk faktörlerinin dağılımı

\begin{tabular}{|c|c|c|c|}
\hline Majör risk faktörleri & Depresyonu olan $\mathrm{n},(\%)$ & Depresyonu olmayan $n,(\%)$ & $\mathrm{p}$ \\
\hline 65 yaş üstü olmak & $55(96,5)$ & $61(89,7)$ & 0,144 \\
\hline Vertebral kompresyon kırığı & $32(56,1)$ & $5(7,4)$ & $0,0001 *$ \\
\hline Fragilite kırı̆̆ı & $2(3,5)$ & $2(2,9)$ & 0,857 \\
\hline Ailede kırık hikayesi & $3(5,3)$ & $12(17,6)$ & $0,0001 *$ \\
\hline Steroid kullanımı (3 ay üzerinde) & $1(1,8)$ & $3(4,4)$ & 0,400 \\
\hline Malabsorbsiyon & 0 & 0 & \\
\hline Düşmeye yatkınlık & $14(24,6)$ & $2(2,9)$ & $0,0001^{*}$ \\
\hline Hipogonadizm & 0 & 0 & \\
\hline Erken menapoz (45 yaş öncesi) & $11(19,3)$ & $9(13,2)$ & 0,357 \\
\hline Primer hiperparatiroidi & 0 & 0 & \\
\hline Osteopeni & $11(19,3)$ & $5(7,4)$ & $0,046^{*}$ \\
\hline \multicolumn{4}{|l|}{ Minör risk faktörleri } \\
\hline Romatoid Artrit & $1(1,8)$ & $2(2,9)$ & 0,666 \\
\hline Geçirilmiş hipertiroidi & $3(5,3)$ & $3(4,4)$ & 0,824 \\
\hline Antikonvülzan kullanımı & 0 & $1(1,5)$ & 0,358 \\
\hline Diyette yetersiz kalsiyum alımı & $43(75,4)$ & $41(60,3)$ & 0,072 \\
\hline Sigara kullanımı & $8(14)$ & $13(19,1)$ & 0,449 \\
\hline Aşrırı alkol tüketimi (Haftada 3 birimden fazla) & 0 & 0 & \\
\hline Aşırı kafein tüketimi (Günlük 330 mg dan fazla) & 0 & 0 & \\
\hline 57 kilo altında olmak & 0 & 0 & \\
\hline 25 yaşındaki Vücut ağırlığının \%10 daha fazlasının kaybı & 0 & 0 & \\
\hline Heparin tedavisi almak & 0 & 0 & \\
\hline Majör risk faktörü ortalaması & $2,12 \pm 1,32$ & $1,41 \pm 0,73$ & $0,0001^{*}$ \\
\hline Minör risk faktörü ortalaması & $1,10 \pm 0,69$ & $0,11 \pm 0,72$ & 0,134 \\
\hline
\end{tabular}

Tablo 3. Depresyonu olan ve olmayan osteoporoz hastalarının kemik mineral yoğunluğu değerlerinin karșllaștırıması

\begin{tabular}{|c|c|c|c|}
\hline & $\begin{array}{c}\text { Depresyonu } \\
\text { olan } \mathbf{n = 5 7}\end{array}$ & $\begin{array}{c}\text { Depresyonu } \\
\text { olmayan } \mathbf{n = 6 8}\end{array}$ & $\mathbf{p}$ \\
\hline Lomber T değeri & $3,53 \pm 0,69$ & $3,16 \pm 0,50$ & $0,0001^{*}$ \\
\hline Lomber Z değeri & $1,58 \pm 0,70$ & $1,33 \pm 0,56$ & $0,032^{*}$ \\
\hline Femur T değeri & $2,66 \pm 0,70$ & $2,38 \pm 0,66$ & $0,022^{*}$ \\
\hline Femur Z değeri & $1,02 \pm 0,59$ & $0,80 \pm 0,41$ & $0,016^{*}$ \\
\hline *:Indepent sample t testi $p<0,05$ istatistiksel olarak anlaml \\
\hline
\end{tabular}

tabloda gösterilmiştir (Tablo 2). Majör risk faktörlerinden vertebral kompresyon kırığı, ailede kırık hikayesi, düşmeye yatkınlık ve osteopeninin depresyonu olan grupta depresyonu olmayanlardan istatistiksel olarak anlamlı olarak fazla olduğu, diğer risk faktörleri açısından karşılaştırıldığında iki grup arasında istatistiksel olarak anlamlı farklılık olmadığı görülmektedir.

Vertebra dışı kırık, depresyonu olan osteoporoz hastalarının 2 'sinde $(\% 3,5)$, depresyonu olmayan osteoporoz hastalarının 2 'sinde $(\% 2,9)$ bulunmaktaydı. Bu fark istatistiksel olarak anlamlı değildi $(p=0,857)$. Sırt ağrısının değerlendirildiği
GAS ortalamaları depresyonu olan osteoporoz hastalarında $(7,42 \pm 2,29)$ depresyonu olmayanlardan $(4,32 \pm 1,81)$ daha yüksek olduğu bulundu ( $p=0,0001)$.

Depresyonu olan ve olmayan osteoporoz hastalarının KMY ve QUALEFFO yaşam kalitesi ölçeği skor ortalamalarının karşılaştırılması ilgili tabloda gösterilmiştir (Tablo 3, 4). Lomber ve femur $T$ ve $Z$ değerlerinin depresyonu olan osteoporoz hastalarında depresyonu olmayanlardan istatistiksel olarak daha yüksek olduğu görülmektedir $(p<0,05)$. QUALEFFO yaşam kalitesi ölçeğinin ağrı, fiziksel işlev, sosyal işlev, ruh hali, genel sağlık algılamasından oluşan tüm alt parametrelerinin ve toplam değerinin depresyonu olan osteoporoz hastalarında depresyonu olmayanlardan istatistiksel olarak anlamlı şekilde yüksek olduğu bulundu $(p<0,05)$.

Beck Depresyon Ölçeği skoruyla yaş, lomber $T$ ve $Z$ değerleri, femur $T$ ve $Z$ değerleri arasında zayıf güçte pozitif anlamlı korelasyon; QUALEFFO yaşam kalitesi ölçeğinin alt parametre skorlarından ağrı, fiziksel işlev, sosyal işlev ve toplam skor arasında orta, genel sağlık algılaması skoru arasında zayıf güçte pozitif anlamlı korelasyon bulundu (Tablo 5). 


\section{Tartışma}

Insan ruhsal ve bedensel komponenti olan bir varlık olduğu için holistik yaklaşım içinde değerlendirildiğinde artmış kemik kaybının sadece kemikleri ilgilendiren bir olay olmadığı açıktır. Osteoporoz mobilite kaybına neden olarak, ağrıya yol açarak, bireyin günlük aktivitelerini kısıtlayarak sosyal aktiviteyi azaltmakta, izolasyona neden olmakta, duygu durumunu olumsuz etkilemekte, kendine güvenin azalmasına ve yaşam kalitesinin daha da bozulmasına neden olmaktadır (14). Bianchi ve ark.ları osteoporoz hastalarının \%40'da depressif semptomların olduğunu göstermiştir (15). 1990'dan beri osteoporozda depresyon varlığını gösteren çalışmalar yapılsa da depresyonun neden mi sonuç mu olduğu açıklığa kavuşturulamamıştır (16). Çünkü osteoporoz hastada ağrı, kırık, deformiteler, fonksiyonel kayıp, sosyal rol kaybı (bireyler ve aileyle), sosyal iletişimde başarısızlık ve sosyal izolasyona ve dolayısıyla da depresyona yol açmaktadır (16). Bunun yanında depresyon da kemik kaybı için risk faktörüdür ve bu mekanizma şöyle açıklanmaktadır (17). Depresyonda CRH (kortikotropinreleasing hormon) salınımı artmakta, ACTH (adrenokortikotropik hormon) salınımını arttırmakta ve hiperkortizolemiye yol açmaktadır. CRH artışılla sempatik sistem aktive olmakta, katekolamin salınımı artmakta ve IL-6 gibi kemik rezorbsiyonu yapan proinflamatuar sitokin salınımı artmaktadır. Yine $\mathrm{CRH}$ artışıla GnRH (gonadotropin releasing hormon) azalmakta ve buna bağlı östrojen ve progesteron, büyüme hormonu, insulin like growth factor (IGF)-1 salınımı azalmaktadır. Artan kortizol ve IL-6, azalan seks steroidleri ve büyüme hormonu hem kemik yapımının azalmasına hem de yıkımın artmasına yol açmaktadır. Tüm bunlarla kemik yapımı, osteokalsin ve ALP azalmaktadır. Osteokalsinin fizyolojik miktarı pankreasta insülin salınımını ve adipoz dokuda adiponektin salınımını düzenlemektedir. Bu durumda leptin ve insülin salınımı artmaktadır. Leptinin sıçanlarda sempatik sistemi aktive ederek kemik formasyonunu inhibe ettiği gösterilmiştir (17). Bu kompleks endokrin ve immun dengesizlik depresyonlu hastalarda osteoporoz oluşumuyla sonuçlanmaktadır (17).

Yapılan çalışmalarda depresyonun pre ve post menapozal kadınlarda artmış fraktür riskiyle ilişkili olduğu gösterilirken erkeklerde bu ilişki kurulmamıştır (18). Bunun aksine osteoporozla ilişkili depresyonda östrojenin rolünün çok az olduğuna dikkat çekilmiştir. Yapılan çalışmalarda depresyonlu hastalarla kontrol grubu arasında menarş yaşı, gebelik sayısı, oral östrojen kullanımı, düzensiz mentrüel siklus arasında büyük bir farklııı saptanmamıştır (19-25). Fakat bu durumda depresyonla ilişkili kıııların kadınlarda erkeklerden daha çok olmasını açıklamak güçleşmektedir (17). Çalışmamızda da osteoporotik bireylerde depresyon gelişiminde cinsiyetin risk faktörü olmadığı görüldü. Daha önce bu konuda yapılan çalışmalar ya osteoporotik erkekler ya da osteoporotik kadınlarda depresyonla ilişkili faktörleri araştırdığı için çalışmamızın osteoporozda depresyon gelişiminde cinsiyetin etkisini ortaya koyması dikkat çekicidir. Yine çalışmamızda aktif çalışma durumu ve medeni durumun depresyon gelişimi için risk faktörü oluşturmadığı, eğitim seviyesinin düşük olmasının ise depresyona yatkınlık oluşturduğu gösterildi.
Sigara içiminin kemik kaybıyla ilişkili olduğu bilinmektedir (25). Birkaç çalışmada depresyonlu osteoporotik bireylerin daha yüksek sigara içme oranına sahip olduğu, birkaç çalışmada da sigara içmenin osteoporozda depresyon için risk oluşturmadığı gösterilmiştir $(20,21,23,24,26-28)$. Çalışmamızda da osteoporotik bireylerde depresyon gelişimi için sigara içiminin risk oluşturmadığı gözlendi. Osteoporoz için risk faktörlerinden birisi de alkol tüketimidir (24). Bazı çalışmalarda depresyon ve kontrol grubunda alkol kullanımın oranlarının benzer olduğu bazı çalışmalarda da depresyonlu osteoporotik bireylerde alkol alımının düşük olduğu ve bu yüzden alkol alımının depresyon ve düşük kemik kütlesi ilişkisinde önemli bir faktör olmadığı ifade edilmiştir $(17,20,25,27,28)$. Bununla uyumlu olarak çalışmamızda da osteoporozda depresyon gelişiminde alkol kullanımının etkisinin olmadığı gösterildi.

Bireylerin osteoporozla fiziksel aktivitesi azalmakta, vücut kompozisyonu değişmekte ve sağlıkla ilişkili riskler artmaktadır (29). Genel olarak depresyonlu osteoporotik bireylerde fiziksel aktivitelerle kemik kütlesinin korunduğu bilinmektedir. Fiziksel aktiviteyle denge, koordinasyon, kas güçlenmesi, reaksiyon zamanı düzelmektedir ve bireyi düşmeye, kırı̆̆a karşı korumaktadır (30). Böylece depresyon oluşumu da azalmaktadır. Lasaite ve ark.larının çalışmasında fiziksel aktivite, emosyonel durum ve yaşam kalitesi skorlarının ilişkili olduğu bulunmuştur (2). Biz de çalışmamızda azalmış fiziksel aktivite düzeyinin osteoporozda depresyon gelişimi için risk faktörü olduğunu gösterdik.

Düşük VKi osteoporoz ve fraktürler için iyi bilinen bir risk faktörüdür (17). Postmenapozal kadınlarda düşük VKi kötü emosyonel durumun neden olduğu düşük kemik mineral içeriğiyle de ilişkilidir (31). Bizim hastalarımızda ise bunlardan farklı olarak depresyonu olan ve olmayan osteoporoz hastaları arasında VKi açısından farklılık bulunmamaktaydı.

Yapılan çalışmalarda depresyon ve kontrol grubu arasında diyetle kalsiyum alımı veya kalsiyum desteği açısından farklıık bulunmamıştır $(17,20,23,27,28)$. Bizim çalışmamızda diyette yetersiz kalsiyum alımı açısından depresyonu olan ve olmayan osteoporotik bireyler arasında farklılık bulunmadı.

Çalışmamızda osteoporoz risk faktörlerinin depresyon gelişimi üzerine etkisi incelendiğinde majör risk faktörlerinden vertebral kompresyon kırığı, ailede kırık hikayesi, düşmeye yatkınlık, osteopeninin depresyona eğilim oluşturduğu gösterildi. Hsiao ve ark.larnın çalışmasında ise yaş, ailede osteoporoz hikayesi, kahve ve çay tüketiminin emosyonel bozukluk ve düşük KMY değeriyle ilişkili olduğu gösterilmiştir (32).

Yapılan araştırmalarda depresyonu olan erkeklerde kontrol grubuna göre total femur kemik kütlesinin daha düşük olduğu gösterilmiştir (28,33). Depresyonu olan kadınlarla kontrol grubu arasında ise hem lomber hem de femur kemik kütlesi arasında farklılık olmadığı gösterilmiştir $(26,34)$. Başka bir çalışmada da postmenpozal osteoporozlu kadınlarda düşük KMY değerleriyle depresyonun ilişkisinin olmadığı gösterilmiştir (35). Her iki cinsiyeti içeren çalışmamızda depresyonu olan osteoporotik bireylerin hem lomber hem de femur KMY değerlerinin depresyonu olmayan osteoporotik bireylerden daha düşük olması, Beck depresyon skoru arttıkça KMY değerlerinin 
Tablo 4. Depresyonu olan ve olmayan osteoporoz hastalarının QUALEFFO yașam kalitesi ölçeği skor ortalamalarının karșılaștırılması

\begin{tabular}{|l|c|c|c|}
\hline & Depresyonu olan $\mathbf{n = 5 7}$ & Depresyonu olmayan $\mathbf{n = 6 8}$ & $\mathbf{p}$ \\
\hline Ağrı & $61,57 \pm 23,55$ & $25,88 \pm 13,29$ & $0,0001^{*}$ \\
\hline Fiziksel işlev & $45,30 \pm 13,52$ & $20,41 \pm 13,90$ & $0,0001^{*}$ \\
\hline Sosyal işlev & $55,26 \pm 10,48$ & $37,70 \pm 13,06$ & $0,0001^{*}$ \\
\hline Genel sağlık algılaması & $68,20 \pm 17,49$ & $53,10 \pm 11,02$ & $0,0001^{*}$ \\
\hline Ruh hali & $64,11 \pm 9,39$ & $60,13 \pm 10,62$ & $0,030^{*}$ \\
\hline Total skor & $58,83 \pm 8,04$ & $34,69 \pm 5,42$ & $0,0001^{*}$ \\
\hline *:Indepent sample t testi $p<0,05$ istatistiksel olarak anlaml & & & \\
\hline
\end{tabular}

Tablo 5. Beck depresyon skorunun yaș, risk faktör ortalaması kemik mineral yoğunluğu değerleri ve QUALEFFO yașam kalitesi ölçeğinin alt parametre skorlarılla ilișkisi

\begin{tabular}{|l|c|c|}
\hline & BDS r & BDS p \\
\hline Yaş & 0,342 & $0,0001^{*}$ \\
\hline Majör risk faktör ortalaması & 0,360 & $0,0001^{*}$ \\
\hline Minör risk faktör ortalaması & 0,202 & $0,024^{*}$ \\
\hline Lomber T skoru & 0,366 & $0,0001^{*}$ \\
\hline Lomber Z skoru & 0,240 & $0,0001^{*}$ \\
\hline Femur T skoru & 0,188 & $0,036^{*}$ \\
\hline Femur Z skoru & 0,193 & $0,031^{*}$ \\
\hline QUALEFFO Ağrı & 0,711 & $0,0001^{*}$ \\
\hline QUALEFFO Fiziksel isslev & 0,657 & $0,0001^{*}$ \\
\hline QUALEFFO Sosyal İşlev & 0,627 & $0,0001^{*}$ \\
\hline QUALEFFO Genel Sağlık Algılaması & 0,474 & $0,0001^{*}$ \\
\hline QUALEFFO Ruh Hali & 0,108 & $0,023^{*}$ \\
\hline Total QUALEFFO & 0,834 & $0,0001^{*}$ \\
\hline BDS: Beck Depresyon Skoru \\
*:Pearson korelasyon analizi p<0,05 İstatistiksel olarak anlamlı
\end{tabular}

düşmesi aralarındaki ilişkiyi açıkça ortaya koymuştur. Giovanni ve ark.ları da depresyonun düşük KMY değerleri için bir risk faktörü olduğunu göstermişlerdir (17). Peki düşük KMY değeri depresyon için risk faktörümüdür yoksa depresyon mu düşük KMY için risk faktörüdür? Bunu gösterecek longitidunal, kontrollü, iyi kurgulanmış, depresyonlu bireylerde KMY taraması ve düşük KMY'li bireylerde de depresyon taramasının yapıldığı yeni araştırmalara intiyaç vardır.

Multiple Outcomes of Raloxifene Evaluation çalışmasında vertebral kırı̆ı olan postmenapozal kadınlarda vertebral kırı̆ı olmayan kadınlardan daha fazla depresif semptom olduğu gözlenmiş ama depresyonun kırığın nedeni mi sonucu mu olduğu açıklığa kavuşturulamamıştır (4). Cook ve ark. çalışmalarında, vertebral kırığının osteoporozlu hastaların \%75'inde kronik ağrıya yol açtığını, emosyonel bir stres kaynağı olduğunu, kişinin işini sürdürmesini, rekreasyonel ve sosyal aktivitelere katıımını ileri derecede kısıtladığını rapor ederek, kırık varlığının yaşam kalitesi üzerindeki yıkıcı etkilerinden söz etmişlerdir (36). Bunun yanı sıra vertebral kırığı olan Norveçli kadınlarda sağlıklı kontrollere göre yüksek oranda ağrının anksiyeteye neden olduğu ama depresyona neden olmadığı ifade edilmiştir (37). Bazı hastalarlarda ilk vertebral kırıkda kısıtlılık ve ağrı oluşturmayınca psikososyal etkilenim olmamakta, zamanla bu semptomlar oldukça fonksiyonel disabilite, ağrı ve deformiteyle birlikte psikososyal etkilenim artmaktadır (38). Bir çalışmada subklinik vertebral kıı̆̆ı olan kadınların yaşam kalitesinin ağıı, sosyal fonksiyon, genel sağlık algılaması komponentlerinin daha kötü olduğu gözlenmiştir (35). Bizim çalışmamızda depresyonu olan osteoporotik bireylerde vertebral kompresyon kırı̆ının ve sırt ağrısı ortalamalarının depresyonu olmayanlardan daha fazla olduğu bulundu. Yani vertebral komresyon kırığı ve dolayısıyla hastanın ağrısının olması osteoporotik bireylerde depresyon gelişimini arttırmaktadır. Bu durum depresyonu olan bireylerde yaşam kalitesinin düşük olmasına katkı sağlamıştır. Hartman ve ark.larının çalışmasında da ağrının depresyon, insomni, bozulmuş yaşam kalitesiyle ilişkili olduğu ortaya konmuştur (3).

Orta yaşlı depresyonu olan kadınlarda depresyonu olmayan kadınlara göre vertebra dışı kırık riskinin \%40 arttığı gösterilmiştir (27). Çalışmamızda depresyonu olan ve olmayan hastalar arasında vertebra dışı kırık açısından farklılık bulunmaması literatüre katkı sağlamaktadır.

Osteoporoz yaşam kalitesinde önemli bir role sahiptir ve depresyondan etkilenmektedir. Hartman ve ark.ları premenapozal kadınlarda SF 36'nın emosyonel ve sosyal skor alt gruplarının sağlıklı kontrollerden daha düşük olmasılyla osteoporozda depresyonun yaşam kalitesini düşürdüğünü göstermişlerdir (3). Kırıklar sonucunda da oluşan fiziksel yetersizlik, psikolojik ve sosyal handikaplar yaşam kalitesinin bozulmasını daha da arttırmaktadır. Lasaite ve ark.larının çalışmasında da emosyonel durum ve yaşam kalitesi skorlarının ilişkili olduğu bulunmuştur (2). Çalışmamızda da depresyonu olan osteoporotik bireylerin tüm yaşam kalitesi skorlarının depresyonu olmayan osteoporotik bireylerden yüksek olması ve BDÖ skoru arttıkça yaşam kalitesi skorlarının da artmasıyla depresyonun yaşam kalitesi üzerindeki olumsuz etkisi ortaya konmuştur.

Sonuç olarak çalışmamızda osteoporozlu bireylerde düşük eğitim düzeyi, azalmış fiziksel aktivitenin depresyon gelişiminde risk faktörü olduğunu, osteoporoz risk faktörlerinden de vertebral kompresyon kırığı, ailede kırık hikayesi, düşmeye yatkınlık ve osteopeninin depresyon gelişmine yatkınlık oluşturduğunu saptadık. Depresyonun artmış kemik kaybı olan bu bireylerde yaşam kalitesinin daha da düşmesine neden olduğu ortaya konuldu. 


\section{Kaynaklar}

1. Gold DT. Physical and psychosocial consequences of osteoporotic vertebral fracture (Part 2). Identifying and managing the nonskeletal consequences of osteoporosis. Advances in Osteoporotic Fracture Management 2002;1:74-9.

2. Lasaite L, Krasauskiene A. Psychological state, quality of life, and body composition in postmenopausal women with osteoporosis in Lithuania. Arch Osteoporos 2009;4:85-90.

3. Hartman JM, Berger A, Baker K, Bolle J, Handel D, Mannes A, et al. Quality of life and pain in premenopausal women with major depressive disorder: the POWER Study. Health Qual Life Outcomes 2006;18:4:2

4. Silverman SL, Shen W, Minshall ME, Xie S, Moses KH. Prevalence of depressive symptoms in postmenopausal women with low bone mineral density and/or prevalent vertebral fracture: results from the Multiple Outcomes of Raloxifene Evaluation (MORE) study. J Rheumatol 2007;34:140-4.

5. Gürer G, Şendur ÖF, Aydeniz A, Aydemir AH. Postmenopozal osteoporozda raloksifen ve kalsitonin tedavilerinin bir yıllık sonuçları. ADÜ Tıp Fakültesi Dergisi 2006;7:15-8.

6. Gökçe Kutsal Y. Osteoporoz, In: Beyazova M, Gökçe Kutsal Y, edi. Fiziksel tıp ve Rehabilitasyon. $2^{\text {nd }}$ ed. Ankara, Güneş Kitabevi; 2000. p. 2633-59.

7. James WP, Francois PJ. The choice of cut-off point for distinguishing normal body weights from underweight or 'chronic energy deficiency' in adults. Eur J Clin Nutr 1994;48:179-84.

8. Orimo H, Shiraki M, Hayashi $Y$, Hoshino T, Onaya T, Miyazaki S, et al. Effects of $1 \alpha$ hydroxyvitamin D3 on lumbar bone mineral density and vertebral fractures in patients with postmenopausal osteoporosis. Calcif Tissue Int 1994;54:370-6.

9. Spertus IL, Burns J, Glenn B, Lofland K, McCracken L. An inventory for measuring depression. Pain 1961;4:561-71.

10. Hisli N. Beck Depresyon Envanterinin geçerliği üzerine bir çalışma. Psikoloji Dergisi 1988;6:118-22.

11. Lips P, Cooper C, Agnusdei D, Caulin F, Egger P, Johnell O, et al. Quality of life in patients with vertebral fractures: validation of the Quality of Life Questionnaire of the European Foundation for Osteoporosis QUALEFFO. Working party for quality of life of the european foundation for osteoporosis. Osteoporos Int 1999;10:150-60.

12. Koçyigit H, Gülseren S, Erol A, Hizli N, Memis A. The reliability and validity of the Turkish version of Quality of Life Questionnaire of the European Foundation for Osteoporosis (QUALEFFO). Clin Rheumatol 2003;22:18-23.

13. Http://www.iofbonehealth.org/health-professionals/healtheconomics/quality-of-lifequaleffo41/downloads.html.

14. de la Loge C, Sullivan K, Pinkney R, Marquis P, Roux C, Meunier PJ. Cross-cultural validation and analysis of responsiveness of the QUALIOST: QUAlity of Life questionnaire in Osteoporosis. Health Qual of Life Outcomes 2005;3:69.

15. Bianchi ML, Orsini MR, Saraifoger S, Ortolani S, Radaelli G, Betti S. Quality of life in post-menopausal osteoporosis. Health Qual Life Outcomes 2005;1:78.

16. Gold DT, Solimeo S. Osteoporosis and depression: a historical perspective. Curr Osteoporos Rep 2006;4:134-9.

17. Cizza G, Primma S, Csako G. Depression as a risk factor for osteoporosis. Trends Endocrinol Metab 2009;20:367-73.

18. Sogaard AJ, Joakimsen RM, Tverdal A, Fonnebo V, Magnus JH, Berntsen GK. Long-term mental distress, bone mineral density and non-vertebral fractures. The Tromso Study. Osteoporos Int 2005; 16:887-97.

19. Altindag O, Altindag A, Asoglu M, Gunes M, Soran N, Deveci Z. Relation of cortisol levels and bone mineral density among premenopausal women with major depression. Int J Clin Pract 2007;61:416-20.
20. Eskandari F, Martinez PE, Torvik S, Phillips TM, Sternberg EM, Mistry S, et al. Premenopausal, Osteoporosis Women, Alendronate, Depression (POWER) Study Group. Low bone mass in premenopausal women with depression. Arch Intern Med 2007; 167:2329-36.

21. Petronijevc M, Petronijevic N, Ivkovic M, Stefanovic D, Radonjic $\mathrm{N}$, Glisic B, et al. Low bone mineral density and high bone metabolism turnover in premenopausal women with unipolar depression. Bone 2008;42:582-90.

22. Yazici AE, Bagis S, Tot S, Sahin G, Yazici K, Erdogan C. Bone mineral density in premenopausal women with major depression. Joint Bone Spine 2005; $72: 540-3$

23. Diem SJ, Blackwell TL, Stone KL, Yaffe K, Cauley JA, Whooley MA, et al; Study of Osteoporotic Fractures. Depressive symptoms and rates of bone loss at the hip in older women. J Am Geriatr Soc 2007; 55:824-31.

24. Kavuncu V, Kuloglu M, Kaya A, Sahin S, Atmaca M, Firidin B. Bone metabolism and bone mineral density in premenopausal women with mild depression. Yonsei Med J 2002:43:101-8.

25. North American Menopause Society. Management of osteoporosis in postmenopausal women: 2006 position statement of The North American Menopause Society. Menopause 2006;13:340-67.

26. Mussolino ME. Depression and hip fracture risk: the NHANES I epidemiologic follow-up study. Public Health Rep 2005;120:71-5.

27. Whooley MA, Kip KE, Cauley JA, Ensrud KE, Nevitt MC, Browner WS. Depression, falls, and risk of fracture in older women. Study of Osteoporotic Fractures Research Group. Arch Intern Med 1999;159:484-90.

28. Mussolino ME, Jonas BS, Looker AC. Hsiao MC, Liu CY, Wang CJ. Depression and bone mineral density in young adults: results from NHANES III. Psychosom Med 2004;66:533-7.

29. Reventlow SD. Perceived risk of osteoporosis: restricted physical activities? Qualitative interview study with women in their sixties. Scand J Prim Health Care 2007;25:160-5.

30. Daley MJ, Spinks WL. Exercise, mobility and aging. Sports Med 2000;29:1-12

31. Tashiro A, Kakuta H, Tanaka N, Takeuchi Y. Relationship between health-related quality of life domains and bone status in postmenopausal Japanese women. Menopause 2006;13:846-9.

32. Hsiao MC, Liu CY, Wang CJ. Factors associated with low bone density among women with major depressive disorder. Int J Psychiatry Med 2012;44:77-90.

33. Esel E, Ozsoy S, Tutus A, Sofuoglu S, Kartalci S, Bayram F, et al. Effects of antidepressant treatment and of gender on serum leptin levels in patients with major depression. Prog Neuropsychopharmacol Biol Psychiatry 2005;29:565-70.

34. Bistrovic IL, Roncevic-Grzeta I, Crncevic-Orlic Z, Franciskovic T, Ljubicic R, Orlic A, Kapovic M. Connection of depression and bone loss in perimenopausal and postmenopausalwomen. Coll Antropol. 2012:36:1219-23.

35. Alekna $V$, Tamulaitiene $M$, Bütenaite $V$. The impact of subclinical vertebral fractures on health-related quality of life in women with osteoporosis. Medicina (Kaunas) 2006:42:744-50.

36. Cook DJ, Guyatt GH, Adachi JD, Epstein RS, Juniper EF, Austin PA, et al. Development and validation of the mini osteoporosis quality of life questionnnaire (QOLQ) in osteoporotic women with back pain dueto vertebral fractures. Osteoporosis Int 1999;10:207-13.

37. Falch JA, Bentzen H, Dahl AA. Pain, functional level and emotional problems of women with osteoporosis and vertebral fractures. Tidsskr Nor Laegeforen.2003;123:3355-7.

38. Haczynski J, Jakimiuk A. Vertebral fractures: a hidden problem of osteoporosis. Med Sci Monit 2001;7:1108-17. 